\begin{tabular}{c} 
Volume and Issues Obtainable at Center for Sustainability Research and Consultancy \\
Sustainable Business and Society in Emerging Economies \\
ISSN: $2708-2172$ \& (E): $2708-2504$ \\
Volume 3: Issue 2 June 2021 \\
CSRC \\
Journal homepage: $\underline{\text { www.publishing.globalcsrc.org/sbsee }}$ \\
\hline
\end{tabular}

\title{
Conceptual Framework for Teaching Sustainable Development Course in Blended Learning Environment
}

*Tilagavati Subramaniam, Faculty of Social Sciences, Quest International University (QIU), Perak, Malaysia

Muthualagan Thangavelu, Faculty of Social Sciences, Quest International University (QIU), Perak, Malaysia

*Corresponding author's email address: thaya.tilaga@gmail.com

\begin{tabular}{l}
\hline ARTICLE DETAILS \\
\hline History \\
Revised format: May 2021 \\
Available Online: Jun 2021 \\
\hline Keywords \\
Sustainable Development \\
Course, Virtual Learning, \\
Curriculum Delivery, \\
Teaching and Learning \\
Strategy
\end{tabular}

\section{JEL Classification}

I23,I25

\section{OPEN ACCESS}

\section{ABSTRACT}

Purposes: This paper presents a conceptual framework for teaching sustainable development courses in an online learning environment in institutions of higher education. Sustainability development courses are becoming essential in higher education institutions mainly to educate the younger generations who will be part of the community to make it happen. Higher education institutions are experiencing dramatic shift to cater a young generation of prospective students, to integrate technical innovations in teaching practices and to concentrate on increasing concerns about global sustainability issues. There has been little research to promote an innovative learning in the teaching of sustainable development. The goal of this paper was to create a framework for teaching sustainable development in a virtual learning environment (blended learning) due to the lack of a conceptual framework that could direct this implementation.

Findings: Hence, the blended learning method is eco-friendly, whereby protects global environmental resources. For hands-on experiences, students will develop projects to make their campus and community more sustainable. In the process, students learn how to analyse sustainability and able to apply online learning knowledge into practice.

Implication: The conceptual framework proposed will support all educators in higher education institutions engaged in the promotion of quality online education in this pandemic circumstance to develop an effective online practise that are aligned with the corresponding learning needs, skills and facilities.

(C) 2021 The authors, under a Creative Commons AttributionNonCommercial- 4.0

Recommended citation: Subramaniam, T. and Thangavelu, M. (2021). Conceptual Framework for Teaching Sustainable Development Course in Blended Learning Environment. Sustainable Business and Society in Emerging Economies, 3 (2), 75-81 


\section{Introduction}

The proliferation of higher education students in internet usage and emerging technology is leading to improvements in curriculum content as well as in teaching and learning methods. An innovative combination of different modes of delivery, teaching models and learning styles can promote this transformation of the teaching and learning environments in higher education settings.

Universities and colleges are undergoing rapid change to cater new generation of incoming students, to integrate advanced technology in teaching practices and to concentrate on increasing concerns about global sustainability issues.

With strong insight into the value and potential challenges of sustainable living, these graduates exit the academic world and join the workforce. Therefore, many higher education institutions have incorporated sustainability as a central part of their teaching objectives in order to create a stronger foundation for students entering society and the marketplace of the 21 st century. Any curriculum reform, including the establishment and inclusion of compulsory sustainability studies, is not a simplistic undertaking and few have certainly succeeded.

This article proposed the conceptual framework to teach sustainable development course as one of the compulsory university courses to the broader student body. Based on the private higher education institution Act 1996 (Act 555), all the student enroll in the private higher education must be taken compulsory courses (MPU course) and considered as must pass the courses for graduating. There is a total of four components in compulsory course U1, U2, U3 and U4 that emphasizes knowledge, skills, morals, value, patriotism, towering personality and community engagement.

The newly established course will be taught as U3, raising awareness of sustainability issues in Malaysia through a compulsory course for first-year students and raising awareness of Sustainable Development Goals (SDGs).

This article intends to present a conceptual framework to teach sustainability course entitled Sustainable development in Malaysia in an online virtual learning environment and implement a project to solve the sustainability issues in the U4 course. Literally to offer recommendations for other higher education institutions plan to undertake a similar endeavour.

\section{Background of Study}

The concept of sustainable development encompasses all facets of financial, societal, and ecological interdependence. The educational strategy is an important way of improving society and becoming an important forum for sustainable development. The Education for Sustainable Development aspect was first officially recognised by the 1992 Earth Summit in Rio de Janeiro, which developed Agenda 21.

The new 2030 Sustainable Development Plan clearly illustrates the importance of integrating the Sustainable Development Education Standards into all levels of education. Education is reiterated by the 17 Sustainable Development Goals (SDGs) as a primary priority for leading to more sustainable and inclusive communities. Therefore, higher education institutions play a significant role in creating knowledge and application of this knowledge on sustainable development in society through the process of education, outreach and service to the community. Tertiary education is the last destination for students before they enter society. Improvements in values and attitudes, skills and behaviour, particularly through a broad awareness of concerns on sustainable development, can be accomplished through education (Ng, Wee, Ariffin, Shabudin \& Hassan, 2020).

Most current research to date has explored the learning outcomes and competencies of educational programmes that transform the students to become change agents towards sustainability (Cebrián, Junyent \& Mulà, 2020). This mirrors the lack of conceptual framework in innovative teaching and learning in higher education institutions. Leading to a shortage of a conceptual framework that could 
direct this integration, the aim of this paper was to establish a framework for teaching sustainable development in a virtual learning environment (blended learning).

\section{Literature Review}

\section{The Concept of Blended Learning}

Blended learning is an approach to be a useful interactive experience in the teaching of sustainable development. According to Caird and Roy (2019), Blended learning designs will promote sustainable development, including the social, economic and environmental aspects of sustainability, and secure global environmental resources for reaching the needs of current and future generations. This method of learning includes the thoughtful combination of face-to - face learning with online learning. Blended learning offers lecturers and students the ability to work together and connect with each other in the field of education, so that learning experiences can be better gained. Blended learning is a blend of multimedia technology, virtual classroom, voicemail, email and conference calls, online text animation and video streaming.

Blended learning is a learning concept that uses conventional approaches to incorporate e-learning methods that can offer solutions, advantages and is very useful both in and out of the classroom to provide students with an in-depth learning experience (Rasmitadila, Widyasari, Humaira, Tambunan, Rachmadtullah, \& Samsudin, 2020). Changing or restructuring the learning system to educate a current generation is one way of achieving learning objectives, especially in tertiary education.

The blended learning concept can be used to offer students an enjoyable learning experience, a deep and meaningful learning experience. (Puspita \& Hasyim, 2019). Furthermore, blended learning is an environmentally friendly learning experience that helps to create a source-saving society (Yao, 2019). Blended learning shows a learning transformation that relies on the use of technology advancement that is combined with conventional education, such as face-to - face learning, which is the new learning process in the modern period.

\section{Course development and structure}

The course synopsis is to introduce students to sustainability and sustainable development through an examination of the United Nations' Sustainable Development Goals. This course will help students understand the environmental, social, and economic challenges faced by Malaysia and how to overcome these challenges.

\section{Course Title: Sustainable Development}

Course code: XXX

\section{Course learning outcomes:}

CLO 1: Discuss the relevance of the Sustainable Development Goals to Malaysia.

CLO2: Evaluate current issues, and their implications, related to the Sustainable Development Goals in local and national contexts.

CLO3: Create a positive social impact project related to selected Sustainable Development Goals.

\section{Course Content Outline:}

Topic1: Overview of sustainable development

Topic 2: 17 Sustainable Development Goals

Topic 3: Sustainability: Issues, challenges and prospects

Topic 4: Implementation of sustainable development through Malaysia's case studies

Topic 5: Developing sustainability-oriented programmes

\section{Assessment Method:}

1. Group Project

2. Individual assignment

3. Presentation

4. Online participation 


\section{Conceptual Framework Proposed for Sustainable Development Course in Blended Learning}

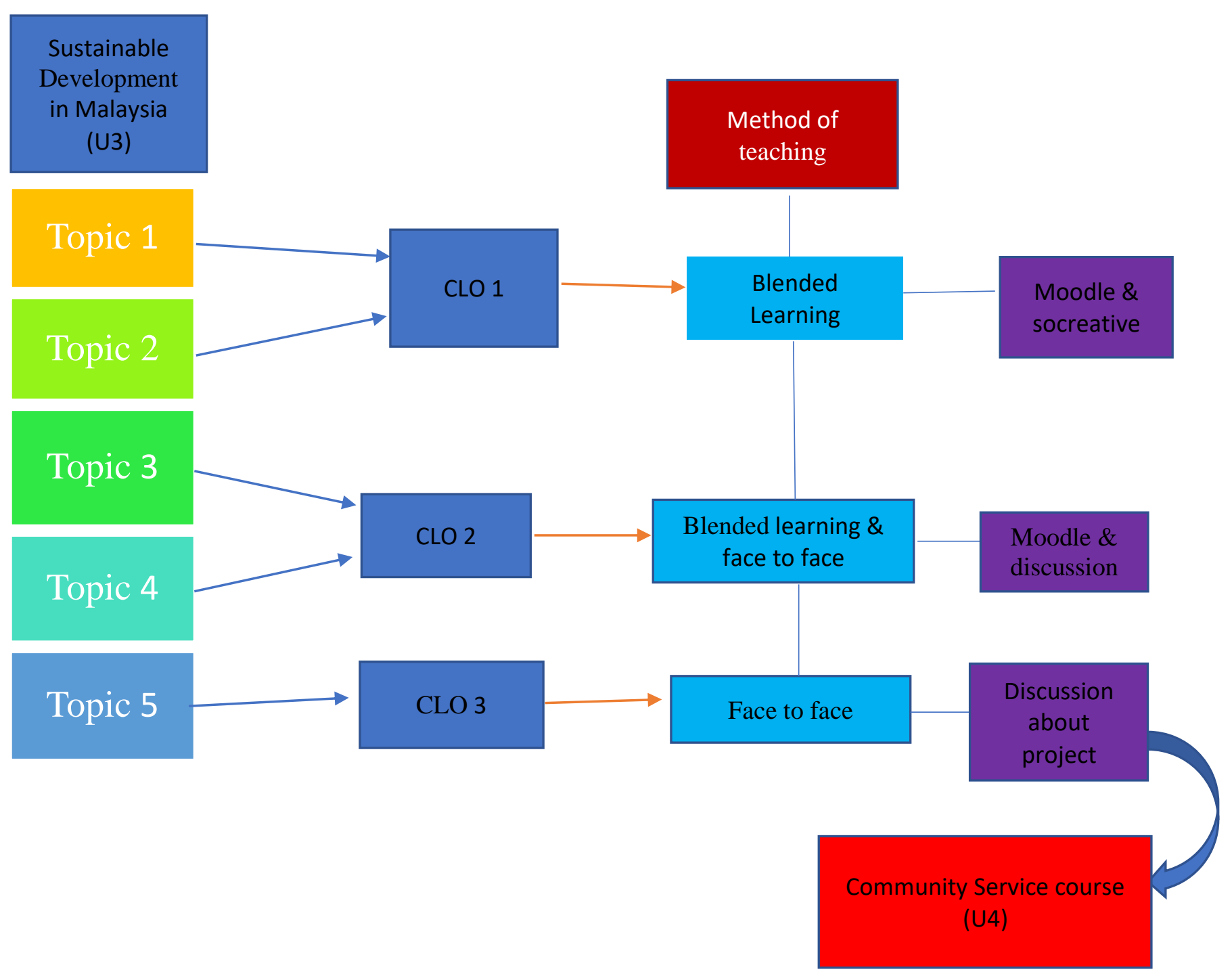

Figure 1

\section{Discussion}

According to Soria \& Weiner (2013), Sustainable development course has the ability to enhance the instructive teaching environment for university students by linking knowledge and experience. The findings of a study by Soria and Weiner (2013) contribute to an idea for the advantages of integrating teaching elements into virtual courses and contribute to a hypothesis that explains how real-world connections improve students' learning. It is essential to discuss the implication of having a sustainable development course in a blended learning setting since its statistically proven that electronic learning is increase in tertiary education. In results, the students would be capable of applying everything they have discovered in a blended learning setting that incorporates with the physical and virtual environments. 


\section{The Applications of Blended Learning Method in Sustainable Development (SD) Course.}

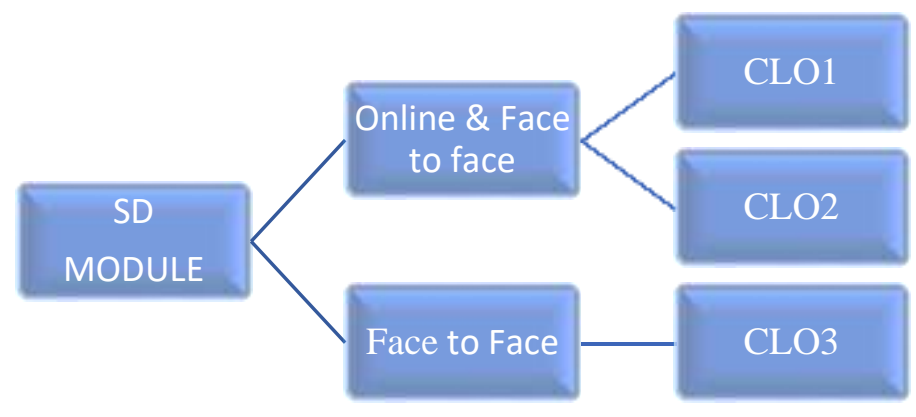

Figure 2

Community of Inquiry (CoI) is a framework developed by Garrison and Randy (2011) distinguishes three main components that are essential for constructing knowledge in a virtual learning course. The level of motivation and performance increases as the level of presence improves. As an outcome, researchers have recognized that in order to achieve instructional goals in learning, students need guidance from teachers or more professional peers. (Reiser, 2002; Kazlauskas \& Applebee, 2007). Some of the related online tools that can use in online learning would be like moodle, socreative, blendspace, edpuzzle and many more.

Apart from that, an instrument like forum discussions, chat room, comment boxes which are also widely employed in the eLearning context. Learners can communicate using computer-mediated communication methods such as forum discussion. As opposed to synchronous face-to-face conversations, research indicates that asynchronous online discussions are much better for information co-construction since there is more scope for reflection and positive contributions (Wang, Shen \& Ritterfeld, 2009).

Based on CLO1 - Discuss the relevance of the Sustainable Development Goals to Malaysia and CLO2Evaluate current issues, and their implications, related to the Sustainable Development Goals in local and national contexts.

Students will be expected to understand SD, current issues of SD and implications of nine fundamental goals of SD. This CLOs covers the essential topics of the overall module of SD. Thus, the mixed approach or blended learning would be one of the best methods that can be used to achieve those course learning outcomes. Finding demonstrates that studying without appropriate guidance from teachers causes students to feel lonely, lack self-confidence, lose motivation, and struggle to complete the complex assignment. It will induce the students to lose concentration on their studies, as well as their hopes and enthusiasm for furthering their skills and knowledge (Holmes, Birds, Seay, Smith \& Wilson, 2010).

\section{For CLO3, - Create a positive social impact project related to selected Sustainable Development} Goals.

As mentioned in the proposed framework, students are required to "engaged in a collaborative and reflective process which includes understanding an issue or problem, searching for relevant information, connecting and integrating information, and actively confirming the understanding". Students will be able to construct the implications of Sustainable Development, or in other words, students will develop their "Cognitive Presence". The essence of the learning environment in raising awareness improvements 
is cognitive presence (Garrison \& Randy, 2011). It refers to a student's ability to comprehend course material and engage in an efficient online forum based on a real event, discovery, adaptation, and resolution in this proposed conceptual framework. In this blended learning course, each link is focused on CLOs to maximize the learning outcome by creating a conducive teaching and learning atmosphere. Students are expected to collaborate on information and have discussions in an online community in order to fix the issues and achieve the objective by vanquish challenges in the mission.

\section{Implication and Conclusion}

This paper illustrates online learning (blended learning) can be used to facilitate teaching for a sustainable development course in compulsory courses (MPU) to bridge face-to-face classroom interaction and out-of-classroom learning experience. Academics or university teachers may take the opportunity to use online learning to completely incorporate their teaching and learning. The instructor may set an online teaching and learning platform like "Moodle" or "Google classroom" for example, that could encourage students to connect with them in a more exciting and less stressful way. Since students can access to the online platform every day anyway, the tendency that the students might miss any essential academic-related announcements, information or instructions is minimal. This will allow students not only to keep track of any recent information from their educators, but it will also provide them with the ability to discuss their academic problems synchronously or asynchronously across the online platform, for instance. In short, university scholars should make effective use of everything that the online platform has to give to carry their teaching and learn outside traditional lectures so that it can help both teachers and students. In addition, while being linked on an online platform, students may also make proper use of their time to do something much more valuable instead of only doing the normal on an online platform.

In order to accommodate the various areas in the course, the syllabus teaching approaches were updated to incorporate instructional techniques like seminars, workshops, sustainability projects and online games. An online platform such as socrative, coggle, edpuzzle and blendspace should be developed to encourage online learning. This type of online learning benefits for the students, because these applications allow voice recording, and the voice recording might be used as comments and suggestions for the teaching and learning activities. Further, these applications can also be downloaded on multiple devices, particularly smartphones, so that students and instructors can use the feature to make learning more casual and enjoyable.

The students were expected to prepare and implement a sustainability project instead of teaching a sustainable development course using blended learning. It is basically a project in which they had to discuss their project with the teacher and under the guidance and supervision of a teacher, created a plan to explain their chosen project and execute the project. This real-world initiative is capable of achieving sustainable development goals, raising awareness, providing students with the information and skills for lasting lifestyle behavioural change and active involvement in social issues. In addition, the course and project help to forge sustainable goals for the academic, administrative and stakeholder institutions of higher education.

\section{References}

Caird, S., \& Roy, R. (2019). Blended Learning and Sustainable Development. In Encyclopedia of Sustainability in Higher Education (pp. 1-10). Springer, Cham.

Cebrián Bernat, G., Junyent i Pubill, M., \& Mulà Pons de Vall, I. (2020). Competencies in Education for Sustainable Development: Emerging Teaching and Research Developments. Sustainability, 2020, vol. 12, núm. 2, p. 579.

Dewey, J., Education and Experience. Indianapolis, IN: Kappa Delta Pi, 1938,14.

Garrison, D. R. (2011). E-learning in the 21st century: A framework for research and practice. Taylor \& Francis. 
Holmes, B. D., Birds, K., Seay, A. D., Smith, D. B., \& Wilson, K. N. (2010). Cohort learning for graduate students at the dissertation stage. Journal of College Teaching \& Learning (TLC), 7(1).

Ludwig-Hardman, S., \& Dunlap, J. C. (2003). Learner support services for online students: Scaffolding for success. The International Review of Research in Open and Distributed Learning, 4(1).

Ng, T. F., Wee, M. I., Ariffin, F. N., Shabudin, A. F. A., \& Hassan, M. S. (2020). Measuring the Effectiveness of Sustainability-Related Course Towards Strengthening the University's Sustainability Strategy in Teaching and Learning Programmes. In Universities as Living Labs for Sustainable Development (pp. 533-544). Springer, Cham.

Puspita, N., \& Hasyim, U. A. A. (2019). Implementing Blended Learning to Promote Sustainable Teaching and Learning Process in Writing Class. English Education: Jurnal Tadris Bahasa Inggris, 12(1), 120-128.

Rasmitadila, R., Widyasari, W., Humaira, M. A., Tambunan, A. R. S., Rachmadtullah, R., \& Samsudin, A. (2020). Using Blended Learning Approach (BLA) in Inclusive Education Course: A Study Investigating Teacher Students' Perception. International Journal of Emerging Technologies in Learning (iJET), 15(02), 72-85.

Soria, K. M., \& Weiner, B. (2013). A "virtual fieldtrip": Service learning in distance education technical writing courses. Journal of Technical Writing and Communication, 43(2), 181-200.

UN. Agenda for Sustainable Development. Resolution Adopted by the General Assembly on 25

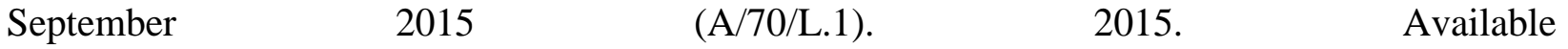
online: http://sustainabledevelopment.un.org/post2015/transformingourworld

Wang, H., Shen, C., \& Ritterfeld, U. (2009). Enjoyment of digital games. Serious games: Mechanisms and effects, 25-47.

Yao, C. (2019). An investigation of adult learners' viewpoints to a blended learning environment in promoting sustainable development in China. Journal of cleaner production, 220, 134-143. 